\title{
Implementasi Diagnosa Penyakit Gastritis Pada Anjing Dengan Menggunakan Jaringan Saraf Tiruan Multi Layer Perceptron (Studi Kasus: Sasmita Pet Shop \& Clinic)
}

\author{
Suryati Manihuruk, Muhammad Syahrizal \\ Program Studi Teknik Informatika, STMIK Budi Darma, Medan, Indonesia \\ Email: manihuruksuryati03@gmail.com \\ Submitted 16-04-2020; Accepted 25-04-2020; Published 26-04-2020
}

\begin{abstract}
Abstrak
Anjing merupakan hewan yang sudah sejak lama dipelihara oleh manusia. Dalam aspek pemeliharaan hewan, ada beberapa hal yang perlu diperhatikan, diantaranya adalah kesehatan. Misalnya bakteri yang ditemukan pada makanan atau air yang dicerna sehingga tanpa disadari hewan tersebut akan mengalami mual dan muntah, Penyakit itu antara lain penyakit gastritis. Penyakit gastritis sama juga deng an penyakit maag. Gastritis berasal dari bahasa Yunani yaitu gastro, yang berarti perut/lambung dan itis yang berarti inflamasi/peradangan. Dari analisa maka diproleh gambaran bahwa jaringan saraf tiruan mendiagnosa penyakit gastritis bisa dilakukan dengan metode multy layer peceptron menggunakan program computer yang sesuai dengan kebutuhan, sehingga pengguna lebih mudah memperoleh hasil diagnose yang lebih baik. Dengan adanya jaringan saraf tiruan mendiagnosa penyakit gastritis ini diharapkan dapat mempermudah dalam melihat nilai bobot yang di inputkan dan hasil diagnose penyakit gastritis
\end{abstract}

Kata Kunci: Gastritis, Multi layer perceptron.

\begin{abstract}
Dog is yab animals already has long maintained by humands in aspect maintenance animals ,there are some hal who need note , among others in health for example bacteria found on food ordigested water so that witout realized animal that is will experience nausea and vomiting,illness that among other diseases gastritis. Gastritis some too with diseases ulcer. Gastritis originated from languagegreece that is gastro, witch means stomach and itis brarti inflammation / inflammation. From analisis then obtained picture that network nerve imitation diagnose gastritis can do with method multi layer perceptron use the appropriate computer program with needs so the user more easyobtain more diagnostic results good. With existence network nerve imitation diagnose gastritis disease expented could make it easier in look value weight in input it and results of diagnosis of the disease.
\end{abstract}

Keywords: Gastritis, Multi Layer Perceptron.

\section{PENDAHULUAN}

Jaringan Syaraf Tiruan (JST) merupakan representasi buatan dari otak manusia yang selalu mencoba mensimulasi proses pembelajaran otak manusia tersebut. Jaringan Syaraf Tiruan merupakan sistem pemrosesan informasi yang memiliki karakteristik kemampuan yang secara umum mirip dengan Jaringan saraf biologi. Jaringan Syaraf mensimulasi struktur proses-proses otak (fungsi Syaraf biologis) dan kemudian membawanya kepada perangkat lunak kelas baru yang dapat mengenali pola-pola yang kompleks serta belajar dari pengalaman masa lalu[1].

Anjing merupakan hewan yang sudah sejak lama dipelihara oleh manusia.. Dalam aspek pemeliharaan hewan, ada beberapa hal yang perlu diperhatikan, diantaranya adalah kesehatan. Misalnya bakteri yang ditemukan pada makanan atau air yang dicerna sehingga tanpa disadari hewan tersebut akan mengalami mual dan muntah, Penyakit itu antara lain penyakit gastritis.

Penyakit gastritis sama juga dengan penyakit maag. Gastritis berasal dari bahasa Yunani yaitu gastro, yang berarti perut/lambung dan itis yang berarti inflamasi/peradangan. Lambung pada dasarnya adalah sebuah kantung otot dimana makanan dicerna. Ketika makanan masuk kelambung, Asam ini amat korosif sehingga paku pun dapat larut dalam cairan ini.Penyakit Gastritis bukanlah suatu penyakit tunggal, namun beberapa kondisi yang berbeda yang semuanya mempunyai peradangan lapisan lambung[2].

Multy layer peceptron adalah jaringan saraf tiruan feed-forward yang terdiri dari sejumlah neuron yang dihubungkan oleh bobot-bobot penghubung, dan disusun oleh beberapa lapisan agar mempermudah kinerja masyarakat yang memelihara hewan yang dapat menghubungkan segala sinyal yang dapat dihubungkan dari bobot-bobot tersebut[3].

Permasalahan yang banyak dihadapi pecinta anjing, sulitnya untuk mengetahui penyakit anjing sehingga terlambat dalam mendiagnosa penyakit yang diderita dan terkadang menyebabkan kematian.Dan biaya konsultasi yang sangat mahal sehingga tidak dapat dijangkau oleh para pecinta anjing yang ekonominya menengah kebawah, selain itu kurangnya rumah sakit hewan khususnya didaerah pedesaan Sehingga diperlukan suatu cara bagi pemilik untuk mengetahui penyakit dan pengobatan berdasarkan dari gejala-gejalanya,.Untuk itu dibutuhkan suatu system untuk mendiagnosa penyakit anjing sehingga dapat memberikan solusi yang baik bagi pemelihara.

Berdasarkan penelitian sebelumnya yang dilakukan oleh Shofwatul Uyun dan Muhammad Fadzlur Volume 2,No. 1, Maret 2013 dengan penelitian yang berjudul "pengenalan wajah dua dimensi menggunakan Multy Layer Peceptron berdasarkan nilai PCA dan LDA" dengan digunakannya metode MLP pengenalan wajah sangat mudah bagi manusia tapi bagaimana system computer dapat mengenal wajah manusia dan dengan bantuan metode MLP sehingga computer dapat mengenal wajah manuisa dengan bobot nilai gambar yang dimasukkan sehingga dapat membantu untuk pengenalan wajah berdasarkan dua dimensi [3]. 
Penelitian selanjutnya dilakukan oleh Lukman dan Imam Sunoto Volume 2 No.1 Agustus2017 yang berjudul" Komparasi Algoritma Multy Layer Peceptron dan support vector machine dalam pemilihan beasiswa" dengan digunakannya metode MLP untuk menentukan siswa yang berprestasi berdasarkan identitas dan data akademik siswa sehingga dapat memberikan masukan pada pihak sekolah untuk mempermudah system dalam memberikan beasiswa[4].

\section{METODE PENELITIAN}

\subsection{Penyakit Gatritis}

Penyakit gastritis sama juga dengan penyakit maag. Gastritis berasal dari bahasa Yunani yaitu gastro, yang berarti perut/lambung dan itis yang berarti inflamasi/peradangan. Lambung pada dasarnya adalah sebuah kantung otot dimana makanan dicerna. Ketika makanan masuk kelambung, Asam ini amat korosif sehingga paku pun dapat larut dalam cairan ini.Penyakit Gastritis bukanlah suatu penyakit tunggal, namun beberapa kondisi yang berbeda yang semuanya mempunyai peradangan lapisan lambung[3].

\subsection{Jaringan Syaraf Tiruan}

Jaringan syaraf tiruan adalah sistem pemprosesan informasi yang memiliki karakteristik, salah satu representasi buatan dari otak manusia yang selalu mencoba untuk mensimulasikan proses pembelajaran pada otak manusia tersebut. Istilah buatan ini digunakan karena jaringan syaraf diimplementasikan dengan menggunakan program komputer yang mampu menyelesaikan sejumlah proses perhitungan selama proses pembelajaran[4]. Ada beberapa jenis tipe jaringan syaraf tiruan, namun demikian hampir semuanya memiliki komponen-komponen yang sama. Seperti halnya otak manusia, jaringan syaraf tiruan juga terdiri dari beberapa neuron dan terdapat hubungan antara neuron tersebut.

\subsection{Metode Multilayer Perceptron}

Multilayer perceptron adalah JST yang paling digunakan dalam bidang pendidikan dan aplikasi. Arsitektur dan proses belajar yang sederhana sangat memudahkan untuk dipelajari. Arsitektur MLP diilustrasikan dibawah ini

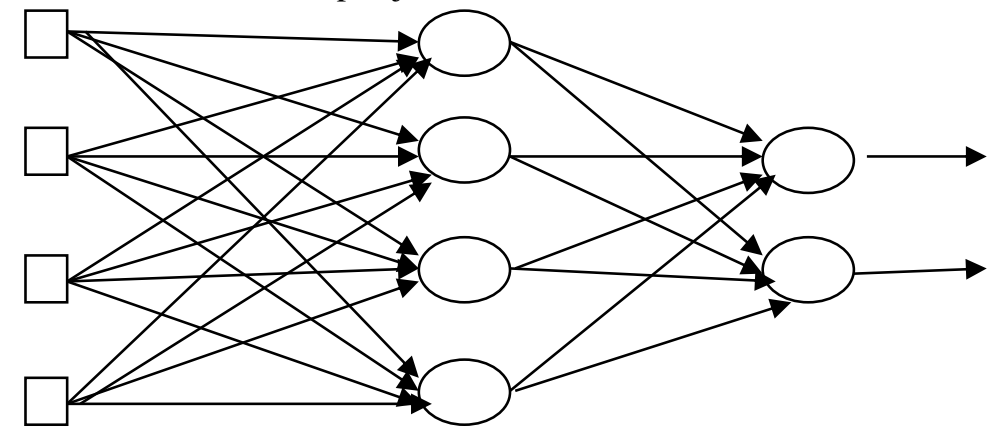

Gambar 1. MLP dengan empat node pada input layer, satu hidden layer dengan empat node, dan dua node pada output layer.

Banyak algoritma yang diusulkan untuk melatih MLP. Salah satu yang populer adalah algoritma pelatihan Back Propagation atau Propagasi Balik. Sesuai dengan namanya, algoritma ini melakuka dua tahap perhitungan yaitu perhitungan maju atau perhitungan mundur untuk menghitung galat antara keluaran aktual dan target, dan perhitungan mundur yang mempropagasikan balik galat terebut untuk memperbaiki bobot-bobot sinaptik pada semua neuron yang ada. Berikut ini langkah-langkah algoritma pelatihan propagasi balik yaitu [6]. :

1. Defenisikan masalah, misalkan matriks masukan $(\mathrm{P})$ dan matriks target $(\mathrm{T})$.

2. Inisialisasikan, menentukan arsitektur jaringan, nilai ambang MSE sebagai kondisi berhenti, learning rate, serta menetapkan nilai-nilai bobot sinaptik melalui pembangkitan nilai acak dengan interval nilai sembarang. Kita bisa membangkitkan nilai acak dalam interval $[-1,+]$ atau $[-0.5,+0,5]$ ataupun lainnya. Tidak ada aturan yang baku mengenai interval ini.

3. Pelatihan Jaringan

a. Perhitungan Maju

Dengan menggunakan bobot-bobot yang telah ditentukan pada inisialisasi awal (W1), kita dapat menghitung keluaran dari hidden layer berdasarkan persamaan berikut (misal kita gunakan fungsi aktivasi sigmoid seperti pada persamaan berikut:

$\mathrm{A} 1=\frac{1}{1+e^{(W 1 * P+B 1)}}$

Hasil keluaran hidden layer (A1) dipakai untuk mendapatkan keluaran dari output layer, seperti pada persamaan berikut:

$\mathrm{A} 2=\mathrm{W} 2 * \mathrm{~A} 1+\mathrm{B} 2$ 
Keluaran dari jarinag (A2) dibandingkan dengan target yang diinginkan. Selisih nilai tersebut adalah error dari jaringan, seperti persamaan berikut:

$\mathrm{E}=\mathrm{T}-\mathrm{A} 2$

Sedangkan nilai galat keseluruhan dinyatakan oleh persamaan berikut:

$\mathrm{SSE}=\sum \sum \mathrm{E}^{2}$

\section{HASIL DAN PEMBAHASAN}

Sampai saat ini, belum banyak tersedia sebuah sistem yang dapat menerapkan kemampuan/pengetahuan dari seorang dokter hewan dalam melakukan diagnosa penyakit pada anjing .Sehingga dengan adanya jaringan saraf tiruan untuk mendiagnosa penyakit pada sistem pencernaan anjing dapat memudahkan dokter hewan maupun masyarakat dalam melakukan diagnosa penyakit gastritis pada anjing, karena jaringan saraf tiruan dirancang untuk menerapkan kemampuan dan pengetahuan dari seorang dokter hewan. Untuk mendiagnosa suatu penyakit perlu diketahui dahulu gejala-gejala penyakit yang ditimbulkan.Meskipun hanya dari gejala klinis (gejala-gejala yang terlihat langsung maupun beberapa penyakit yang diderita), dokter dapat mengambil suatu kesimpulan berupa penyakit yang diderita.Tetapi ada kalanya tertentu. Jaringan saraf tiruan yang akan dibangun merupakan sebuah aplikasi sistem yang berbasis visual basic 2008, yang di mana program viual basic 2008 ini mudah digunakan untuk semua kalangan, baik untuk membantu para pemelihara anjing dalam berkonsultasi ketika tidak bisa datang secara langsung ke dokter hewan, serta membantu pakar (dokter hewan)ataupun petugas klinik dalam mendiagnosis penyakit gastritis pada anjing dengan waktu yang lebih efisien

Berikut ini adalah informasi tentang gejala-gejala penyakit gastritis pada anjing adalah yaitu :

Tabel 1. data jenis gejala kliniks penyakit gastritis

\begin{tabular}{|c|c|c|c|c|c|c|c|c|c|}
\hline $\mathrm{NO}$ & Nama hewan & Muntah & Nafsu makan turun & Dehidrasi & Lesu & Kembung & demam & Diare & Aktif \\
\hline 1 & Dogjy & $\mathrm{X}$ & & $\mathrm{X}$ & & $\mathrm{x}$ & $\mathrm{X}$ & $\mathrm{x}$ & \\
\hline 2 & Hiro & & & $\mathrm{X}$ & $X$ & & $\mathrm{X}$ & $\mathrm{x}$ & $\mathrm{X}$ \\
\hline 3 & Tiffany & & & & & & $\mathrm{X}$ & $\mathrm{x}$ & $\mathrm{X}$ \\
\hline 4 & Dino & $\mathrm{X}$ & & $X$ & $\mathrm{X}$ & $\mathrm{x}$ & $\mathrm{X}$ & $\mathrm{x}$ & $\mathrm{X}$ \\
\hline 5 & Charlie & & & & & & & $\mathrm{x}$ & \\
\hline 6 & Lebra & & & $\mathrm{X}$ & & & & $\mathrm{x}$ & \\
\hline 7 & Dumu & & & $\mathrm{X}$ & & & & $\mathrm{x}$ & $\mathrm{X}$ \\
\hline 8 & Jojo & & & $\mathrm{X}$ & $\mathrm{X}$ & & & $\mathrm{x}$ & $\mathrm{X}$ \\
\hline 9 & Maru & $\mathrm{X}$ & & $\mathrm{X}$ & $\mathrm{X}$ & $\mathrm{x}$ & $\mathrm{X}$ & $\mathrm{x}$ & $\mathrm{X}$ \\
\hline 10 & Coffe & & & & $\mathrm{X}$ & & $\mathrm{X}$ & $\mathrm{x}$ & $\mathrm{X}$ \\
\hline 11 & Summer & & $\mathrm{X}$ & & & & & $\mathrm{x}$ & $\mathrm{X}$ \\
\hline
\end{tabular}

Berikut ini adalah Tabel Gejala dan Bobot Nilai

Tabel 2. Gejala dan Bobot Nilai

\begin{tabular}{llll}
\hline No & Nama Gejala & Nilai Bobot & Diagnosa \\
\hline 1 & Muntah & 1 & 9 \\
2 & Nafsu makan turun & 5 & 8 \\
3 & Dehidrasi & 4 & 7 \\
4 & Lesu & 3 & 3 \\
5 & Kembung & 2 & 1 \\
6 & Diare & 1 & 2 \\
7 & Demam & 1 & 4 \\
8 & Aktif & 1 & 8 \\
\hline
\end{tabular}

\subsection{Penerapan Metode Multy Layer Peceptron}

Dalam jaringan saraf tiruan ini akan digunakan penerapan metode Multy Layer Peceptron dengan perhitungan menggunakan perhitangan maju. Perlu diingat bahwa di dalam Multylayer peceptron kebenaran sembarang pernyatan hanyalah masalah derajat. Dengan menggunakan bobo-bobot yang telah ditentukan pada inisialisasi awal(W1), kita dapat menghitung keluaran dari hidden layer berdasarkan persamaan berikut(missal kita gunakan aktivasi sigmoid dibawah ini.

$\mathrm{A} 1=\frac{1}{1+e\left(w 1^{x} p+B\right)}$

Hasil keluaran hidden layer(A1) dipakai untuk mendapatkan keluaran dari output layer, seperti pada persamaan berikut: $\mathrm{A} 2=\mathrm{W} 2 * \mathrm{~A} 1+\mathrm{B} 2$

Keluaran dari jaringan(A2) dibandingkan dengan target yang diinginkan .Selisih nilai tersebut adalah error(galat) dari jaringanseperti berikut:

$\mathrm{E}=\mathrm{T}-\mathrm{A} 2$ 
Sedangkan nilai galat keseluruhan dinyatakan dalam oleh persamaan berikut: $\mathrm{SSE}=\sum \sum \mathrm{E}^{2}$

\section{Gejala 1}

$\frac{1}{1+e\left(W_{1} * P+B\right)}$

$\frac{1}{1+1(1 \times 9+1)}=\frac{1}{11}=0,09$

$\mathrm{A}^{2=} \mathrm{W} 2 * \mathrm{~A}+\mathrm{B} 1=5 * 0,09+1=1,45$

$\mathrm{E}=\mathrm{T}-\mathrm{A} 2=9-1,45=7,55$

$\mathrm{SSE}=\sum \sum \mathrm{E}^{2}=7,55=15.1$

\section{Gejala 2}

$\frac{1}{1+e\left(w 1^{x} p+B\right)}$

$\frac{1}{1+1(5 \times 8+2)}$

$\frac{1}{43}=0,02$

$\mathrm{A}^{3}=\mathrm{W}^{3 *} \mathrm{~A} 2+\mathrm{B} 2=4 * 1,45+2=7.8$

$\mathrm{E}=\mathrm{T}-\mathrm{A}^{2}=8-1.45=6,55$

$\mathrm{SSE}=\sum \sum \mathrm{E}^{2}=6,55=13,1$

\section{Gejala 3}

$\frac{\frac{1}{1+e\left(w 1^{x} p+B\right)}}{1+1(4 X 7+3)}$

$\frac{1}{32}=0,03$

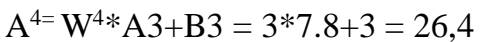

$\mathrm{E}=\mathrm{T}-\mathrm{A}^{3}=7-7,8=0.8$

$\mathrm{SSE}=\sum \sum \mathrm{E}^{2}=0,8=1,6$

\section{Gejala 4}

$\frac{1}{1+e\left(w 1^{x} p+B\right)}$

$\frac{1}{1+1(3 X 3+4)}$

$\frac{1}{14}=0,07$

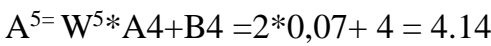

$\mathrm{E}=\mathrm{T}-\mathrm{A}^{4}=3-0,07=2.93$

$\mathrm{SSE}=\sum \sum E 2=2.93=5,86$

\section{Gejala 5}

$\frac{1}{1+e\left(w 1^{x} p+B\right)}$
$\frac{1}{1+1(2 X 1+5)}$
$\frac{1}{8}=0,12$


$\mathrm{A}^{6=} \mathrm{W}^{6 *} \mathrm{~A} 5+\mathrm{B} 5=1 * 0,12+5=5.12$

$\mathrm{E}=\mathrm{T}-\mathrm{A}^{5}=-1-5.12=4,12$

$\mathrm{SSE}=\sum \sum E 2=4,12=8.24$

\section{Gejala 6}

$$
\begin{aligned}
& \frac{1}{1+e\left(w 1^{x} p+B\right)} \\
& \frac{1}{1+1(1 X 2+6)} \\
& \frac{1}{9}=0,11
\end{aligned}
$$

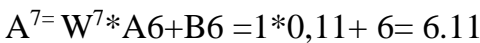

$\mathrm{E}=\mathrm{T}-\mathrm{A}^{7}=2-6.11=4.11$

$\mathrm{SSE}=\sum \sum E 2=4.11=8.22$

\section{Gejala 7}

$$
\begin{aligned}
& \frac{1}{1+e\left(w 1^{x} p+B\right)} \\
& \frac{1}{1+1(1 X 4+7)} \\
& \frac{1}{12}=0,83
\end{aligned}
$$

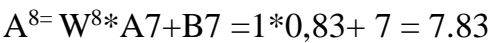

$\mathrm{E}=\mathrm{T}-\mathrm{A}^{2}=4-7.83=3.83$

$\mathrm{SSE}=\sum \sum E 2=3.83=766$

\section{Gejala 8}

$$
\begin{aligned}
& \frac{1}{1+e\left(w 1^{x} p+B\right)} \\
& \frac{1}{1+1(1 X 8+8)} \\
& \frac{1}{17}=0,05
\end{aligned}
$$

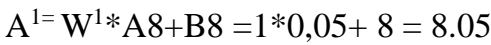

$\mathrm{E}=\mathrm{T}-\mathrm{A}^{2}=8-8.05=0,05$

$\mathrm{SSE}=\sum \sum E 2=0,05=0.1$

Sehingga didapatkan bentuk Hidden layer Multi Layer Perceptron seperti gambar berikut ini:

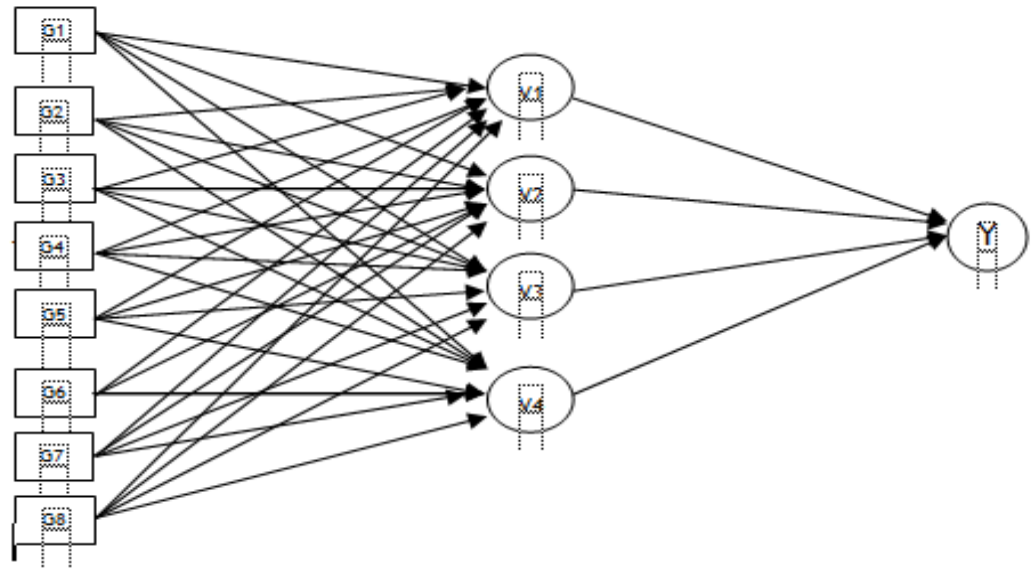

Gambar 2. Hidden layer Multi Layer Perceptron 


\section{KESIMPULAN}

Dari hasil pengujian system yang telah dilakukan. Adapun kesimpulan yang diperoleh dari penelitian diagnosa penyakit gastritis pada anjing yaitu:

1. Dengan menggunakan multi layer perceptron ini pengguna dapat mengetahui gejala-gejala penyakit gastritis pada anjing

2. Dengan menggunakan sistem ini pengguna dapat lebih efektif dan efisien dalam mendiagnosa penyakit gastritis pada anjing

3. Aplikasi ini menggunakan database MySQL dan software bantuan Visual Basic.net 2008 dengan form menu utama, form input data dan form hasil diagnosa penyakit.

\section{REFERENCES}

[1] Idanny Mawarny Butar-Butar, 2017 "Perancangan Simulasi Antrian Pembayaran Rekening Listrik Dengan Model Multiple Channel Single Phase Menggunakan Metode Multilevel Queue” ISSN : 2301-9425 Jurnal Teknik Informatika Vol.16 No.3

[2] Atmodjo, H Marsum Widjojo, Restoran dan Segala Permasalahannya. Yogyakarta : Andi. 2007

[3] Wim J. Winowatan, 2017 “Analisis Kualitas Pelayanan Makanan Dan Minuman Pada Usaha Jasa Pangan” ISSN : 1979-7168 Jurnal Kepariwisataan Vol. 11 No.01

[4] Suyono and Joko, Food Service Management, Bandung: Enhaii Pres.2004

[5] Irzani \& A Mulya Astuti,2012 "Optimalisasi Kualitas Layanan Melalui Analisis Antrian Pada Pusat Pelayanan Mahasiswa Di Fakultas Tarbiyah IAIN Mataram’ ISSN : 2085-5893 Jurnalbeta Vol.5 No.2

[6] M Hasija, A Kaushik, S. Kaushika, \& M. Barnel, ” D-MMLQ Algorithm for Multi-level Queue Scheduling, “ IJCSNS International Journal of Computer Science and Network Security, VOL.14 No.7, July 2014

[7] Rosa A.S, and M. Shalahuddin,Rekayasa Perangkat Lunak. Yogyakarta : Andi, 2011

[8] Lindung Dwi Yunus, Implementasi Android SDK Dalam Pembuatan Aplikasi Mobile "Kalkulator Mipa" Untuk Sekolah Menengah Pertama, p. 3, 2012.

[9] Safaat and Nazruddin, Pemrograman Aplikasi Mobile Smartphone Dan Table PC Berbasis Android. Bandung : Informatika, 2012

[10] M. E. Satyaputra, Alfa, Java For Beginners With Eclipse 4.2 Juno. Jakarta: PT.Alex Media Komputindo, 2012 